\title{
PENGARUH KONSENTRASI PUPUK DAUN TURI PUTIH (Sesbania grandiflora) TERHADAP POPULASI Chlorella sp.
}

\author{
The Effect of Agati (Sesbania grandiflora) Leaf Fertilizer on the Population of Chlorella \\ sp. \\ Maulida Rosa Umainana ${ }^{1}$, Ahmad Shofy Mubarak ${ }^{2}$ dan Endang Dewi Masithah ${ }^{2}$ \\ ${ }^{1}$ Program Studi Budidaya Perairan, Fakultas Perikanan dan Kelautan, Universitas Airlangga, Surabaya \\ ${ }^{2}$ Departemen Manajemen Kesehatan Ikan dan Budidaya Perairan, Fakultas Perikanan dan Kelautan, Universitas \\ Airlangga, Surabaya \\ *maulida@fpk.unair.ac.id
}

\begin{abstract}
Abstrak
Chlorella sp. adalah salah satu pakan alami dalam pembenihan ikan laut karena kandungan protein yang tinggi dan mudah dicerna. Nutrien makro dan mikro dalam media kultur Chlorella sp. sangat penting untuk mendapatkan nilai produktivitas kultur yang tinggi sehingga dapat memenuhi kebutuhan nutrien dari Chlorella sp. Sesbania grandiflora merupakan kelompok tanaman legum memiliki kemampuan bersimbiosis dengan bakteri Rhizobium leguminoserum yang mampu mengikat unsur nitrogen dari udara. Kandungan unsur kimia dalam $S$. grandiflora secara kualitatif dan kuantitatif dapat memenuhi kebutuhan unsur makro dan mikro yang sangat penting bagi pertumbuhan Chlorella sp. Tujuan dari penelitian ini adalah untuk mengetahui pengaruh pupuk $S$. grandiflora terhadap populasi Chlorella sp. dan konsentrasi optimal $S$. grandiflora pada kultur Chlorella sp. Metode penelitian ini adalah eksperimental sedangkan rancangan penelitian yang digunakan adalah Rancangan Acak Lengkap (RAL) dengan 7 perlakuan dan 4 ulangan. Parameter utama dalam penelitian ini yaitu kandungan populasi Chlorella sp., sedangkan parameter penunjang dalam penelitian ini terdiri dari kualitas air media. Hasil penelitian menunjukkan dosis pupuk Sesbania grandiflora yang menghasilkan populasi tertinggi adalah perlakuan $\mathrm{K}\left(10,5 \times 10^{5} \mathrm{sel} / \mathrm{ml}\right)$ yang terjadi pada pada hari kesepuluh diikuti oleh perlakuan B $\left(10,4 \times 10^{5} \mathrm{sel} / \mathrm{ml}\right)$ dan perlakuan $\mathrm{C}\left(9,5 \times 10^{5} \mathrm{sel} / \mathrm{ml}\right)$ yang terjadi pada hari kesepuluh.
\end{abstract}

Kata kunci: Chlorella sp., Populasi Chlorella sp., Pupuk Sesbania grandiflora, Media Kultur

\begin{abstract}
Chlorella sp. is one of natural feed in marine hatcheries because of high protein content and easy to digest. Macro and micro nutrients in culture media of Chlorella sp. is very important to get a high values productivity so that can supply the nutrient requirement of Chlorella sp. Sesbania grandiflora is a groups of legume crops has an ability in symbiosis with Rhizobium leguminoserum that capable to binding the element of nitrogen from the air. Chemical elements in $S$. grandiflora qualitatively and quantitatively able to supply macro and micro elements for Chlorella sp. growth so it has potential to be applied in culture of Chlorella sp. This research method is experimental, determined effect of S. grandiflora fertilizer on population of Chlorella sp. and best concentration of S. grandiflora fertilizer on culture of Chlorella sp. This research method is experimental, while the design of the study is a Randomized Complete Design with 7 treatments and 4 replications. The main parameters in this research is Chlorella sp. population, while the supporting parameter in this study consisted of water quality. The results suggest that dose of liquid Sesbania grandiflora fertilizer that produces the highest population of Chlorella sp. is K treatment (10.575 million cells $/ \mathrm{ml})$ which occurred on the tenth day followed by B treatment (10.462 million cells $/ \mathrm{ml})$ and $\mathrm{C}$ treatment $(9.525$ million cells $/ \mathrm{ml})$ respectively.
\end{abstract}

Keywords: Chlorella sp., Population, Sesbania grandiflora Fertilizer, Culture media

\section{PENDAHULUAN}

Chlorella sp. merupakan alga bersel tunggal dari golongan alga hijau (Chloropyta) yang telah dimanfaatkan secara ko- mersial karena gizinya yang tinggi (Srihati dan Carolina, 1995). Chlorella sp. memiliki peranan dalam memenuhi kebutuhan manusia diantaranya sebagai makanan tambahan 
atau suplemen karena kandungan nutrisinya lengkap (Royan, dkk. 2010). Meningkatnya permintaan akan Chlorella sp. merupakan peluang dilakukannya peningkatan kultur Chlorella sp.

Menurut Eyster (1978) konsentrasi nutrien yang dibutuhkan untuk pertumbuhan Chlorella sp. baik makronutrien dan mikronutrien ditetapkan menjadi tiga yaitu konsentrasi minimum, maksimum, dan optimum. Eyster (1978) mengemukakan bahwa nutrien yang dibutuhkan oleh Chlorella sp. berupa makronutrien dan mikronutrien. Makro-nutrien terdiri dari, N, P, K, Si dan $\mathrm{Ca}$ sedangkan mikronutrien terdiri dari $\mathrm{Fe}$, $\mathrm{Mo}, \mathrm{Cu}, \mathrm{Mn}, \mathrm{Zn}$ dan Co. Unsur yang dibutuhkan untuk pertumbuhan Chlorella sp. antara lain $\mathrm{N}(0,14-0,7 \mathrm{~g} / \mathrm{l})$ dan $\mathrm{P}(0,015-$ $0,62 \mathrm{~g} / \mathrm{l})$.

Kebutuhan unsur makro nutrien dan mikro nutrien dalam kultur Chlorella sp. harus tercukupi untuk pertumbuhan yang optimal terutama unsur $\mathrm{N}$ dan $\mathrm{P}$ yang berfungsi untuk pembentukan klorofil dan keperluan fotosintesis (Sumarlinah, 2000).

Pemenuhan kebutuhan nutrien fitoplankton dapat berasal dari bahan alami misalnya Azolla pinata dan bintil akar kacang tanah (Prabandari. 2011) dan masih memungkinkan untuk menggunakan bahan alami lain, salah satunya Sesbania grandiflora yang memilki N tinggi 10,3\%. Turi Putih (Sesbania grandiflora) adalah tanaman legum dan biasa digunakan sebagai pupuk hijau (Van, 1975).

S. grandiflora bersimbiosis secara mutualistik dengan bakteri Rhizobium pada bintil akar. Rhizobium merupakan bakteri berbentuk batang bulat yang mampu memfiksasi nitrogen dari udara sehingga tanaman $S$. grandiflora memiliki kandung-an nutrisi N tinggi. Duke (1983), Evans \& Rotar (1987) dan Serra et al. (2009) menyatakan bahwa daun $S$. grandiflora memiliki berbagai unsur hara antara lain $\mathrm{N}(10,3$ gram), P (258 mg), K (2005 mg), Fe (3,9 $\mathrm{mg}), \mathrm{Ca}(1684 \mathrm{mg}), \mathrm{Na}(21 \mathrm{mg}), \mathrm{Cu}(5,0$ gram), Zn (30,0 mg), Mo (15,3 mg), Co (1,6 mg) dan Mn (99 mg).
S. grandiflora memiliki kandungan hara yang lengkap. Secara kualitatif (unsur makro dan mikronutrien terpenuhi) dan kuantitatif (jumlah kandungan $S$. grandiflora dapat memenuhi kebutuhan Chlorella sp.) dapat memenuhi kebutuhan unsur makro dan mikro Chlorella sp. sehingga mengurangi ketergantungan terhadap pupuk Walne yang memilki resiko kontaminasi bahan kimia serta harganya yang mahal. Berdasarkan uraian di atas penelitian ini berujuan untuk memanfaatkan konsentrasi terbaik pupuk $S$. grandiflora sebagai sumber makro dan mikronutrien untuk pertumbuhan Chlorella sp. sehingga berpotensi digunakan dalam kultur populasi Chlorella sp.

\section{METODOLOGI}

Waktu dan Tempat

Penelitian dilaksanakan pada bulan April 2012 di Laboratorium Pendidikan Perikanan Fakultas Perikanan dan Kelautan Universitas Airlangga Surabaya.

\section{Metode Penelitian}

Penelitian ini merupakan eksperimen dengan Rancangan Acak Lengkap (RAL) yang terdiri dari 7 perlakuan dan 4 ulangan. Variabel bebas yang digunakan adalah perbedaan dosis dari pupuk Sesbania grandiflora. Variabel tergantung yang digunakan adalah populasli Chlorella sp. Variabel kendali yang digunakan adalah kualitas air media pemeliharaan : suhu, $\mathrm{pH}$ air, salinitas.

\section{Prosedur Penelitian}

Air laut yang akan digunakan untuk kultur disterilisasi dengan menggunakan larutan klorin, air laut disaring terlebih dahulu dengan menggunakan kapas yang diletakkan dalam corong air, kemudian disterilkan dengan khlorin 60 ppm selama 24 jam dan diberi aerasi. Sisa-sisa klorin dihilangkan dengan memberikan $\mathrm{Na}$ Thiosulfat $20 \mathrm{ppm}$ dan diaerasi sampai klorin hilang yang ditandai dengan bau klorin sudah tidak ada.

Peralatan kultur yang akan diguna- 
kan dicuci sampai bersih kemudian dibilas air tawar dan dikeringkan. Untuk peralatan yang terbuat dari kaca tahan panas harus ditutup dengan kapas dan kasa, kemudian dibungkus dengan aluminum foil. Setelah itu disterilisasi menggunakan autoclave pada suhu $121^{\circ} \mathrm{C}$ selama 15 menit. Peralatan yang tidak tahan panas disterilkan dengan larutan khlorin 150 ppm selama 24 jam. Kemudian dibilas dengan air tawar hingga bersih dan bau khlorin hilang.

Larutan pupuk Sesbania grandiflora yang telah dibuat disimpan dalam wadah yang tidak tembus cahaya atau kulkas agar bertahan lama.

\section{Kultur Chlorella sp.}

Lingkungan kultur dalam penelitian ini adalah suhu $28^{\circ} \mathrm{C}$, salinitas 30 ppt. Intensitas cahaya 3000 lux diukur dengan menggunakan luxmeter selama 24 jam dan pemberian aerasi yang cukup.

Bibit Chlorella sp. dimasukkan ke dalam media dengan kepadatan $3,3 \times 10^{5}$ unit $/ \mathrm{ml}$. Penghitungan jumlah bibit Chlorella sp. untuk kultur menggunakan persamaan (Edhy dkk., 2003):

$$
V 1=\frac{N 2 \times V 2}{V 1}
$$

Keterangan:

$\mathrm{V} 1=$ Volume bibit untuk penebaran awal $(\mathrm{ml})$

N1 = Kepadatan bibit $/$ stock Chlorella sp. (unit $/ \mathrm{ml}$ )

$\mathrm{V} 2=$ Volume media kultur yang dikehendaki (L)

N2 = Kepadatan bibit Chlorella sp. yang dikehendaki (unit/ml)

Penghitungan kepadatan Chlorella sp. dilakukan dengan menggunakan Haemocytometer dan Hand tally Counter untuk memudahkan perhitungan kepadatan. Perhitungan dilakukan dengan persamaan 2 (Aujero 1982 dalam Saputro 2010) sebagai berikut :

$$
N=\frac{n A+n B+n C+n D+n E}{5 \times 4 \times 10^{-6}}
$$

Keterangan:

\footnotetext{
$\mathrm{n} \quad=$ jumlah sel fitoplankton pada blok A, B, $\mathrm{C}, \mathrm{D}$ dan $\mathrm{E}$

$5=$ jumlah blok yang dihitung

$4 \times 10^{-6}=$ luas kotak kecil (A, B, C, D atau E)
}

Pengukuran kualitas air pada kultur Chlorella sp. dilakukan setiap hari. Parameter kualitas air yang diamati meliputi suhu, $\mathrm{pH}$ dan salinitas air.

\section{Analisis Data}

Data hasil penelitian ini diolah meng-gunakan analisis ragam atau Analysis of Variance (Anova). Apabila terdapat perbedaan yang nyata, maka analisis data dilanjutkan dengan dengan uji Jarak Berganda Duncan (Duncan's Multiple Range Test).

\section{HASIL DAN PEMBAHASAN}

Pertumbuhan fitoplankton dalam kultur ditandai dengan bertambah besarnya ukuran sel atau bertambah banyaknya jumlah sel yang secara langsung akan berpengaruh terhadap kepadatan fitoplankton (Isnansetyo dan Kurniastuty, 1995). Menurut Edhy dkk., (2003) pertumbuhan fitoplankton terdiri atas lima fase yaitu adaptasi, fase eksponensial, fase penurunan relatif, fase stasioner dan kematian.

Hasil penelitian penambahan pupuk daun $S$. grandiflora menunjukan bahwa pertumbuhan populasi Chlorella sp. mengalami tiga fase pertumbuhan yaitu fase adaptasi, eksponensial dan kematian. Fase adaptasi pada masing-masing perlakuan setelah penambahan inokulan ke dalam media kultur tidak terlihat jelas pada grafik pertumbuhan Chlorella sp. (Gambar 1).

Hal ini dikarenakan fase adaptasi Chlorella sp. terjadi sangat singkat yaitu sebelum 24 jam. Menurut Fogg dan Thake (1987) dalam Prihantini dkk. (2005), salah satu faktor yang menentukan fase adaptasi adalah sel-sel yang diinokulasi cepat beradaptasi terhadap media kultur yang baru sehingga mampu tumbuh dan membelah dengan cepat.

Fase eksponesial merupakan fase yang terjadi setelah fase adaptasi yang ditandai dengan pembelahan sel-sel baru dan laju pertumbuhan tetap. Pada kondisi kultur yang optimum laju pertumbuhan pada fase ini mencapai maksimal (Isnansetyo dan Kurniastuty, 1995). Pertumbuhan Chlorella 
sp. pada fase eksponensial ditandai dengan adanya peningkatan jumlah populasi Chlorella sp. yang dimulai pada hari pertama pengamatan sampai puncak populasi. Pada perlakuan $\mathrm{A}, \mathrm{B}, \mathrm{C}, \mathrm{D}$ dan $\mathrm{K}$ fase eksponensial terjadi selama sepuluh hari yang dimulai dari hari pertama sampai hari kesepuluh sedangkan perlakuan $\mathrm{E}$ dan $\mathrm{F}$ terjadi selama sebelas hari yang dimulai dari hari pertama sampai kesebelas. Faktor yang mempengaruhu fase eksponensial yaitu suhu, $\mathrm{pH}$, intensitas cahaya, jumlah inokulan, laju pertumbuhan dan kemampuan plankton menyerap nutrien.

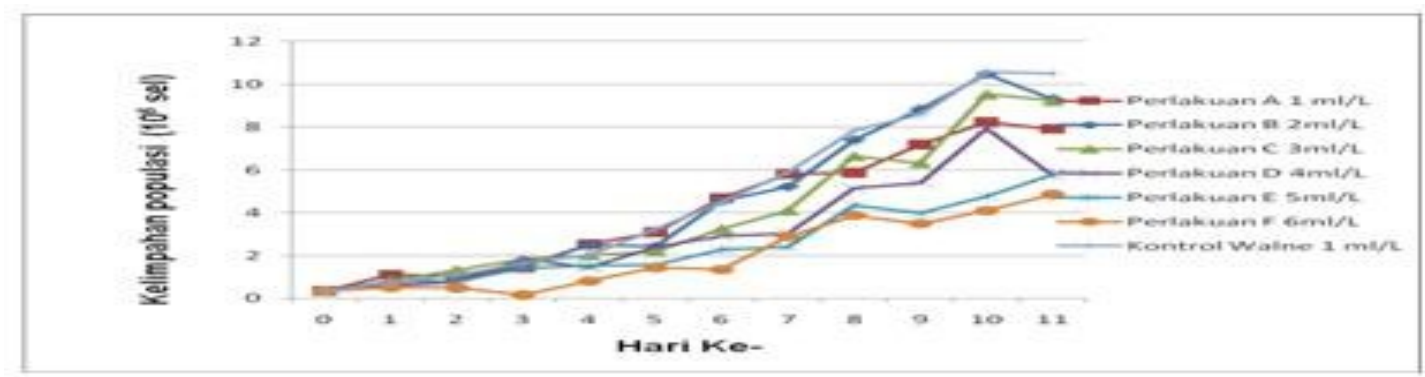

Gambar 1. Grafik Populasi Chlorella sp. dengan Pupuk S. grandiflora

Tabel 1. Data Rasil Transformasi Rata-rata Populasi Chlorella sp. dengan penambahan Pupuk S. grandiflora

\begin{tabular}{c|c|c|c|c|c|c|c|}
\hline \multirow{2}{*}{ Hari } & \multicolumn{7}{|c|}{ Perlakuan } \\
\cline { 2 - 8 } & $\mathbf{A}$ & $\mathbf{B}$ & $\mathbf{C}$ & $\mathbf{D}$ & $\mathbf{E}$ & $\mathbf{F}$ & K \\
\hline 0 & 574.4563 & 574.4563 & 574.4563 & 574.4563 & 574.4563 & 574.4563 & 574.4563 \\
\hline 1 & $1048.809^{\mathrm{a}}$ & $821.5838^{\mathrm{b}}$ & $901.3878^{\mathrm{ab}}$ & $766.4855^{\mathrm{b}}$ & $894.4272^{\mathrm{ab}}$ & $715.8911^{\mathrm{b}}$ & $866.0254^{\mathrm{b}}$ \\
\hline 2 & $1012.423^{\mathrm{a}}$ & $1054.751^{\mathrm{a}}$ & $1151.086^{\mathrm{a}}$ & $858.7782^{\mathrm{ab}}$ & $887.412^{\mathrm{ab}}$ & $698.212^{\mathrm{b}}$ & $1030.776^{\mathrm{a}}$ \\
\hline 3 & $1198.958^{\mathrm{ab}}$ & $1239.96^{\mathrm{ab}}$ & $1355.544^{\mathrm{a}}$ & $1350.926^{\mathrm{a}}$ & $1183.216^{\mathrm{ab}}$ & $387.2983^{\mathrm{b}}$ & $1284.523^{\mathrm{ab}}$ \\
\hline 4 & $1585.087^{\mathrm{a}}$ & $1577.181^{\mathrm{a}}$ & $1418.626^{\mathrm{a}}$ & $1204.159^{\mathrm{ab}}$ & $1239.96^{\mathrm{ab}}$ & $894.4272^{\mathrm{b}}$ & $1414.214^{\mathrm{a}}$ \\
\hline 5 & $1757.128^{\mathrm{ab}}$ & $1557.241^{\mathrm{bc}}$ & $1479.02^{\mathrm{c}}$ & $1549.193^{\mathrm{bc}}$ & $1244.99^{\mathrm{d}}$ & $1193.734^{\mathrm{d}}$ & $1792.345^{\mathrm{a}}$ \\
\hline 6 & $2162.175^{\mathrm{a}}$ & $2133.073^{\mathrm{ab}}$ & $1799.305^{\mathrm{abc}}$ & $1702.939^{\mathrm{bc}}$ & $1508.31^{\mathrm{c}}$ & $1156.503^{\mathrm{d}}$ & $2115.42^{\mathrm{ab}}$
\end{tabular}

Keterangan : Superskrip berbeda dalam satu kolom menunjukkan ada perbedaan yang nyata $(\mathrm{p}<0,05)$.

Perlakuan A : Pupuk S. Grandiflora $1 \mathrm{ml} / \mathrm{L}$; Perlakuan B : Pupuk S. Grandiflora $2 \mathrm{ml} / \mathrm{L}$; Perlakuan C : Pupuk $S$. Grandiflora $3 \mathrm{ml} / \mathrm{L}$; Perlakuan D : Pupuk S. Grandiflora $4 \mathrm{ml} / \mathrm{L}$; Perlakuan E : Pupuk S. Grandiflora $5 \mathrm{ml} / \mathrm{L}$; Perlakuan F : Pupuk S. Grandiflora $6 \mathrm{ml} / \mathrm{L}$; Perlakuan K : Pupuk Walne $1 \mathrm{ml} / \mathrm{L}$

Hasil ANOVA $(\mathrm{p}<0,05)$ dari penelitian ini menunjukkan setiap perlakuan penambahan konsentrasi pupuk daun $S$. grandiflora memberikan pengaruh yang berbeda nyata terhadap populasi dari Chlorella sp. Artinya, penambahan pupuk daun $S$. grandiflora mempengaruhi besarnya populasi Chlorella sp. Penambahan pupuk daun $S$. grandiflora 1-3 ml memberikan laju pertumbuhan tinggi yang tidak berbeda nyata dengan pemberian pupuk Walne. Penambahan pupuk daun $S$. grandiflora lebih dari $3 \mathrm{ml}$ memberikan laju pertumbuhan yang lebih rendah.

Populasi Chlorella sp. yang berbeda nyata dipengaruhi oleh nutrien yang ter- kandung dalam pupuk $S$. grandiflora yang meliputi unsur makro maupun mikro meliputi $\mathrm{N}, \mathrm{P}, \mathrm{K}, \mathrm{Fe}, \mathrm{Mn}, \mathrm{Cu}, \mathrm{Zn}$ dan $\mathrm{Mg}$ yang mampu memenuhi kebutuhan nutrien Chlorella sp.

Hasil uji laboratorium menunjukan kandungan nutrien $\mathrm{N}, \mathrm{P}, \mathrm{Fe}$ dan $\mathrm{Mg}$ pada daun $S$. grandiflora cukup tingi yaitu sebesar $0,58 \%, 0,04 \%, 0,0021 \%$ dan $0,0015 \%$, dimana unsur utama yang dibutuhkan dalam kultur Chlorella sp adalah N dan P. Nutrien utama yang paling dibutuhkan fitoplankton bagi pertumbuhan adalah Nitrogen dalam bentuk nitrat (Nybakken 1988). 
Menurut Riyono (2007), nitrogen merupakan bagian dari pembentukan klorofil dan protein. Fosfor berperan dalam transfer energi di dalam sel dalam bentuk ATP (Supono, 2009). Menurut Eyster (1978), konsentrasi N, P, F dan Mg mempengaruhi pembentukan klorofil dan metabolisme (fotosintesis) dimana hasil fotosintesis digunakan untuk pertumbuhan plankton sehingga konsentrasi tiap perlakuan juga memberikan pengaruh yang berbeda pada pertumbuhan Chlorella sp.

Konsentrasi $\mathrm{N}$ berlebih akan menghambat pertumbuhan karena tidak terjadi pembentukan protoplasma baru, bila konsentrasi $\mathrm{N}$ rendah dapat menghambat proses biosintesis sel alga dan pertumbuhan vegetatif berlebihan sedangkan konsentrasi $\mathrm{P}$ berlebih maka akan menghambat proses asimilasi senyawa $\mathrm{P}$ bagi pertumbuhan, bila konsentrasi $\mathrm{P}$ rendah akan mengganggu proses pembentukan ATP sehingga pertumbuhan sel terbatas (Richmond ,1986).

Konsentrasi pupuk daun $S$. grandiflora $2 \mathrm{ml} / \mathrm{L}$ menunjukan populasi Chlorella sp. sebesar 10,4 × $10^{5} \mathrm{sel} / \mathrm{ml}$ yang tidak berbeda dengan penggunaan pupuk Walne $1 \mathrm{ml} / \mathrm{L}$ sebesar $10,5 \times 10^{5} \mathrm{sel} / \mathrm{ml}$. Pemberian pupuk daun $S$. grandiflora konsentrasi $2 \mathrm{ml}$ menunjukan populasi yang sepadan dengan pupuk walne pada kultur Chlorella sp. Pupuk daun S. grandiflora termasuk pupuk yang memilki $\mathrm{N}$ dan $\mathrm{P}$ tinggi sehingga sesuai diberikan pada Chlorella sp. untuk meningkatkan pertumbuhan plankton.

Hal ini terbukti dari puncak populasi Chlorella sp. yang lebih tinggi dibandingkan dengan penggunaan pupuk Azolla pinata dengan kepadatan puncak 1,2 x $10^{5}$ $\mathrm{sel} / \mathrm{ml}$ dan pupuk cair limbah Lemuru dengan kepadatan puncak $3 \times 10^{6} \mathrm{sel} / \mathrm{ml}$ sehingga pupuk daun $S$. grandiflora lebih baik dikembangkan untuk populasi Chlorella sp. Tingginya populasi Chlorella sp. yang diberi pupuk $S$. grandiflora disebabkan oleh tingginya kandungan $\mathrm{N}$ dan $\mathrm{P}$ yaitu $0,58 \%$ dan $0,04 \%$, sedangkan pupuk Azolla pinata sebesar 0,28\% dan 0,04\% (Jannah, 2011) dan limbah Lemuru sebesar $2,1 \%$ dan $0,73 \%$ (Meritasari, 2011).

Selain itu, rasio N/P pupuk daun $S$. grandiflora sebesar 14,5:1 lebih mendekati kebutuhan rasio N/P Chlorella sp. dibandingkan pupuk Azolla pinata sebesar 7:1 dan pupuk limbah Lemuru sebesar 2,8:1. Hasil penelitian Eyster (1978) diketahui bahwa kebutuhan rasio N/P Chlorella sp. sebesar 9,3:1. Kandungan $\mathrm{N}$ dan $\mathrm{P}$ pada pupuk sangat dibutuhkan plankton karena merupakan salah satu unsur penting bagi pertumbuhan plankton, pembentuk protein dan klorofil (Kennish, 1994 dalam Retnani, 2011).

Puncak populasi Chlorella sp. dengan perlakuan penambahan pupuk daun $S$. grandiflora terjadi pada hari kesepuluh. Puncak populasi pada hari kesepuluh yaitu perlakuan A, B, C dan D. Puncak populasi perlakuan $\mathrm{E}$ dan $\mathrm{F}$ belum terjadi hingga hari kesebelas. Pada perlakuan E dan F konsentrasi penambahan pupuk daun $S$. grandiflora lebih banyak. Hal ini menyebabkan air pada media kultur keruh sehingga cahaya sulit menembus dan pertumbuhan plankton menjadi lambat sehingga ketercapaian puncak populasi lebih lama. Selain itu ketersedian nutrien yang lebih tinggi memperpanjang waktu kultur (Wetzel, 2001).

Fase kematian merupakan fase akhir dari pola pertumbuhan fitoplankton. Fase kematian ditandai dengan penurunan jumlah/kepadatan plankton. Fase kematian terlihat pada perlakuan A, B, C, D dan K pada hari kesebelas, sedangkan perlakuan $\mathrm{E}$ dan $\mathrm{F}$ belum mengalami fase kematian pada hari kesebelas. Fase kematian disebabkan oleh kekurangan oksigen, temperatur tinggi, gangguan $\mathrm{pH}$, kontaminasi maupun umur plankton itu sendiri dan berkurangnya proses fotosintesis akibat bertambahnya jumlah sel (kepadatan plankton) sehingga hanya bagian permukaan kultur saja yang memperoleh cahaya hal ini mengakibatkan plankton akan berebut $\mathrm{CO}_{2}$ dan $\mathrm{O}_{2}$ (Riley and Chester, 1971 dalam Nugraheny, 2001). 
Ketersediaan nutrien yang semakin berkurang tiap harinya juga merupakan faktor kematian bagi plankton. Selain itu adanya toksik yang dihasilkan oleh mikroalga dari hasil metabolisme yang meracuni mikroalga itu sendiri. Menurut Pomeroy (1991) dalam Sumarlinah (2000) bahwa laju pertumbuhan fitoplankton akan sebanding dengan meningkatnya konsentrasi nutrien hingga mencapai suatu konsentrasi yang jenuh. Setelah keadaan ini, partumbuhan fitoplankton tidak tergantung lagi pada konsentrasi nutrien. Pada penelitian ini tidak terdapat fase penurunan relatif dan fase stasioner.

Pada penelitian ini umur dari kultur plankton dapat mencapai 11 hari. Hal ini dikarenakan adanya unsur vitamin B12 dalam pupuk walne maupun pupuk daun $S$. grandiflora yang berfungsi memperpanjang umur dari kultur Chlorella sp. Terpenuhinya unsur makro dan mikro nutrien serta vitamin B12 yang memacu pertumbuhan dapat mempertahankan kehidupan Chlorella sp. lebih lama. Namun ada faktorfaktor lain yaitu kualitas air yang mendukung seperti $\mathrm{pH}$, suhu, salinitas serta pencahayaan yang optimal (Tabel 2), kualitas bibit yang baik dan jumlah inokulan.

Tabel 2. Rata - rata Kisaran Kualitas Air Selama Penelitian

\begin{tabular}{|c|c|}
\hline Parameter & Kisaran \\
\hline Suhu Air & $28-32^{\circ} \mathrm{C}$ \\
\hline Suhu Ruang & $29-31{ }^{0} \mathrm{C}$ \\
\hline Salinitas & $28-55 \mathrm{ppt}$ \\
\hline $\mathrm{pH}$ & $7-9$ \\
\hline
\end{tabular}

Faktor lingkungan yang mendukung pertumbuhan Chlorella sp. adalah suhu air, suhu ruangan, salinitas dan $\mathrm{pH}$ (Isnansetyo dan Kurniastuty, 1995). Hasil pengukuran suhu air selama selama penelitian berkisar antara 28-32 ${ }^{\circ} \mathrm{C}$. Menurut Isnansetyo dan Kurniastuty (1995) suhu optimal untuk Chlorella sp. skala laboratorium adalah 25$30^{\circ} \mathrm{C}$. Salinitas pada media pemeliharaan Chlorella sp. berkisar antara 30-55 ppt. Salinitas media pemeliharaan mengalami peningkatan disebabkan kenaikan suhu. Menurut Meadows and Campbell (1988) dalam Samsigianti (2010) penguapan dipengaruhi oleh tingginya suhu, semakin tinggi penguapan maka salinitas juga semakin tinggi. Nilai $\mathrm{pH}$ pada media pemeliharaan Chlorella sp. selama penelitian adalah 79,8 . Parameter $\mathrm{pH}$ dapat digunakan untuk mengetahui ketersediaan $\mathrm{CO}_{2}$ pada media kultur yang dimanfaatkan sebagai fotosintesis. Prihantini et al. (2005) dalam Prabowo (2009) menyatakan bahwa $\mathrm{pH}$ yang sesuai dengan pertubuhan Chlorella sp. berkisar antara 4,5-9,3.

\section{KESIMPULAN DAN SARAN Kesimpulan}

Konsentrasi pupuk daun Sesbania grandiflora memberikan pengaruh yang berbeda nyata terhadap populasi Chlorella sp. Selain itu penambahan pupuk daun Sesbania grandiflora perlakuan B dengan konsentrasi $2 \mathrm{ml} / \mathrm{L}$ dapat menghasilkan populasi Chlorella sp. yang tertinggi sebesar $10,4 \times 10^{5} \mathrm{sel} / \mathrm{ml}$.

\section{Saran}

Pupuk daun Sesbania grandiflora dapat digunakan pada kultur Chlorella sp. perlakuan B dengan konsentrasi optimal 2 $\mathrm{ml} / \mathrm{L}$ yang panen hari ke sepuluh hampir mendekati jumlah populasi Chlorella sp. pada perlakuan pemberian pupuk Walne 1 $\mathrm{ml} / \mathrm{L}$ sehingga pemberian pupuk daun $S$. grandiflora dapat digunakan sebagai pengganti pada pupuk Walne dalam kultur Chlorella sp.

\section{DAFTAR PUSTAKA}

Chowdhury, S. A., K. S. Huque and M. Khatun. 2001. Algae in Animal Production. Animal Production research Division, Bangladesh Livestock Research Institute. Bangladesh. Pp 1-13.

Duke, J. A. 1983. Handbook of Energy Crops (Sesbaniagrandiflora (L.) Pers. University Purdue.West Indian pea.Pp 4. (unpulished) 
Edhy, W. A., J. Pribadi dan Kurniawan. 2003. Plankton di Lingkungan PT. Central Pertiwi Bahari Suatu Pendekatan Biologi dan Manajemen Plankton Dalam Budidaya Udang. Laboratorium Central Department Aquaculture Division PT. Central Pertiwi Bahari.

Evans, D. O and P. P. Rotar. 1987. Sesbania in Agriculture. Westriew Press. London. Pp 192.

Eyster, C. 1978. Nutrient Concentration Requirements for Chlorella sorokiniana. Available from the author or the Mobile college Library, Mobile, Alabama 36613. p 78-81.

Panggabean, L. dan Sutomo. 1995. Pengaruh Limbah Budidaya Ikan terhadap Pertumbuhan Chlorella sp. Puslit Oseanografi. LIPI. Hal 183188.

Prabandari, K. 2011. Pengaruh Penambahan Rendaman Akar Kacang Tanah Sebagai Sumber Nitrogen dan Fosfor Terhadap Populasi Chlorella sp. Skripsi. Fakultas Perikanan dan Kelautan. Universitas Airlangga. Surabaya.

Royan, M. R., Khomaruddin., M. D. Arifi dan Minto. 2010. Chlo-Juice (Jus Chlorella) Sebagai Minuman Multivitamin Berkhasiat, Berkalsium, Dan Berprotein Tingi Serta Sebagai Peluang Usaha Multiprofit. PKMK. Universitas Airlangga. Surabaya. 16 hal.

Saputra, H. 2010. Pemanfaatan Blotong Kering sebagai Pupuk untuk Peningkatan Pertumbuhan Populasi Dunaliella salina. Skripsi. Fakultas Perikanan dan Kelautan.Universitas Airlangga. 64 hal.

Serra, S. D., A. B. Serra, T. Ichinohe, T. Harumoto and T. Fujihara. 1996. Amount and Distribution of Dietery Minerals in Selected Philippine Forages. Faculty of Agriculture, Shimane University, Matsue-shi, Shiname. Japan, 9 (2) : 139-147.
Srihati dan Carolina.1997. Pengaruh Berbagai Media Terhadap Kualitas Algae Bersel Tunggal (Scenedesmus sp.) Lembaga Ilmu Pengetahuan Indonesia.LIPI. Hal 877-882.

Sumarlinah. 2000. Hubungan Komunitas Fitoplankton dan Unsur Hara N dan P di Danau Sunter Selatan, Jakarta Utara. Skripsi. Program Studi Manajemen Sumberdaya Perairan, Fakultas Perikanan, Institut Pertanian Bogor. Bogor. 62 hal. 